\title{
APLIKASI REGRESI LOGISTIK DALAM ANALISIS FAKTOR RISIKO ANEMIA GIZI PADA MAHASISWA BARU IPB
}

\author{
(Logistic Regression Application on Analysis of Risk Factors of Nutritional Anemia \\ Among New Students of IPB) \\ Indah Irma Maharani ${ }^{1}$, Hardinsyah ${ }^{2}$ dan Bambang Sumantri ${ }^{3}$
}

ABSTRACT

This study was aimed at analyzing risk factors of nutritional anemia among new students of Bogor Agricultural University (IPB). A logistic regression model for 1907 new students' record data matched with health record data was selected and applied on anemia risk factors analysis. The result showed that $10.9 \%$ and $21.4 \%$ of the students were suffering from nutritional anemia and proteinuria respectively. The risk factors of nutritional anemia among the new students of IPB are sex, age, family income and proteinuria status. The nutritional anemia risk is higher among female students $(O R=1.36)$; among younger age (age < 18 year); among students from low income family $(O R=1.70)$; and students suffered from proteinuria $(O R=1.49)$. This implies that the regular monitoring and controlling of both anemia and proteinuria among the students by Polyclinic of IPB are urgently required.

Keywords: risk factors, nutritional anemia, proteinuria

\section{PENDAHULUAN}

\section{Latar Belakang}

Berbagai masalah gizi masih diderita oleh sebagian masyarakat di Indonesia dan salah satu masalah gizi utama adalah anemia gizi yang umumnya disebabkan oleh kekurangan zat besi.

Anemia adalah suatu keadaan kekurangan kadar hemoglobin $(\mathrm{Hb})$ dalam darah yang terutama disebabkan oleh kekurangan zat gizi (khususnya zat besi) yang diperlukan untuk pembentukan $\mathrm{Hb}$ tersebut (Depkes, 1998). Di Indonesia sebagian besar anemia disebabkan oleh kekurangan zat besi ( $\mathrm{Fe}$ ) sehingga disebut anemia kekurangan zat besi atau anemia gizi besi. Anemia ini sering juga disebut sebagai penyakit kurang darah yang biasanya ditandai dengan gejala cepat lelah, kurang bergairah, tidak mampu berkonsentrasi, kurang selera makan, pusing, sesak nafas, mudah kesemutan, merasa mual dan jantung berdebar-debar (Husaini dan Karyadi, 1978).

Anemia gizi karena kekurangan zat besi ini dapat terjadi karena pola konsumsi makanan masyarakat Indonesia masih didominasi pangan nabati, sedangkan pangan hewani se-

\footnotetext{
${ }^{1}$ Alumni Jurusan Statistika, Fakultas Matematika dan IPA (FMIPA), IPB.

${ }^{2}$ Staf Pengajar Departemen Gizi Masyarakat, Fakultas Ekologi Manusia (FEMA), IPB.

${ }^{3}$ Staf Pengajar Departemen Statistika,

Fakultas Matematika dan IPA (FMIPA), IPB
}

perti daging dan susu sebagai sumber zat besi yang baik (heme iron) jarang dikonsumsi penduduk. Di samping itu, keadaan tertentu seperti kebutuhan yang meningkat pada masa remaja, kehamilan, mengidap penyakit seperti TBC dan malaria, kehilangan darah, kekurangan zat gizi lainnya, dan kecacingan, akan memperberat masalah anemia gizi (Depkes, 1998).

Remaja, termasuk mahasiswa baru, merupakan salah satu kelompok yang rawan terhadap masalah anemia gizi. Hal ini dapat dimaklumi karena masa remaja adalah masa pertumbuhan yang lebih banyak membutuhkan zat gizi termasuk zat besi. Hasil Survei Kesehatan Rumah Tangga (SKRT) 1995 dalam Depkes (1998) menunjukkan bahwa $57.1 \%$ remaja putri (usia 10 - 14 tahun), 39.5\% wanita usia subur (usia 15 - 44 tahun) dan $50.9 \%$ ibu hamil menderita anemia. Berdasarkan laporan poliklinik IPB dari hasil pemeriksaan kesehatan yang dilakukan pada bulan Juni 2002 diperoleh data bahwa sekitar 40\% mahasiswa baru menderita paling tidak salah satu jenis penyakit dan salah satunya adalah menderita anemia gizi.

Menurut Soekirman (2000), anemia pada remaja dapat menimbulkan berbagai dampak antara lain menurunnya konsentrasi belajar dan menurunnya stamina dan produktivitas kerja. Di samping itu remaja yang menderita anemia, kebugarannya juga akan menurun (Depkes, 1998). 
Mengingat cukup seriusnya dampak yang ditimbulkan akibat anemia tersebut, menarik kiranya untuk mengkaji faktor-faktor risiko terjadinya anemia pada remaja, khususnya mahasiswa USMI IPB tahun 2002/2003. Hasil penelitian ini diharapkan nantinya dapat menjadi sumber informasi yang bermanfaat bagi berbagai pihak yang berkepentingan dalam menentikan langkah-langkah penanggulangan anemia gizi khususnya bagi mahasiswa IPB.

\section{$\underline{\text { Tujuan }}$}

Penelitian ini bertujuan untuk menentukan faktor risiko anemia gizi pada mahasiswa Undangan Seleksi Masuk IPB (USMI) ${ }^{4}$ tahun 2002/2003.

\section{METODE PENELITIAN}

\section{Data}

Data yang digunakan dalam penelitian ini merupakan data sekunder mahasiswa USMI IPB 2002/2003 yang diperoleh dari tim poliklinik IPB (data penyakit), Panitia Penerimaan Mahasiswa Baru IPB (data sosial ekonomi), dan klinik Gizi \& Diet GMSK (data status gizi). Jumlah keseluruhan data mahasiswa USMI IPB 2002/ 2003 dari data penerimaan mahasiswa baru adalah sebanyak 1992 mahasiswa, sedangkan jumlah mahasiswa USMI IPB 2002/2003 yang mengikuti pemeriksaan kesehatan oleh tim Poliklinik IPB dan Klinik Gizi \& Diet GMSK adalah sebanyak 1988 mahasiswa. Setelah kedua file data tersebut digabungkan, didapatkan jumlah mahasiswa yang memiliki data kesehatan dan status sosial ekonomi sebanyak 1959 mahasiswa. Setelah dilakukan cleaning data, didapat sebanyak 1907 mahasiswa yang memiliki keterangan data lengkap yang untuk selanjutnya digunakan dalam penelitian ini.

Peubah respon yang digunakan adalah peubah berskala biner tentang status anemia gizi mahasiswa yang ditentukan berdasarkan kadar hemoglobin $(\mathrm{Hb})$ mahasiswa yang bersangkutan, yaitu status anemia $=1(Y=1)$ untuk mahasiswa yang mengalami anemia gizi (Kadar $\mathrm{Hb} \geq 12 \mathrm{~g} / 100 \mathrm{ml}$ ) dan status tidak anemia $=0(Y=0)$ untuk mahasiswa yang tidak mengalami anemia (Kadar $\mathrm{Hb}<12 \mathrm{~g} / 100 \mathrm{ml}$ ).

Peubah-peubah penjelas yang digunakan terdiri atas :

\footnotetext{
${ }^{4}$ Sekitar $80 \%$ mahasiswa baru IPB adalah mahasiswa jalur USMI yang berasal dari hampir semua kabupaten/kota di Indonesia.
}

1. J enis Kelamin. Merupakan peubah biner dengan nilai 1 untuk mahasiswa perempuan dan nilai 0 untuk mahasiswa laki-laki.

2. Umur. Merupakan peubah biner dengan nilai 1 untuk mahasiswa yang berumur 18 tahun ke atas dan bernilai 0 untuk mahasiswa yang berumur kurang dari 18 tahun.

3. Pendidikan Ibu. Menyatakan tingkat pendidikan tertinggi ibu yang merupakan peubah biner dengan nilai 1 untuk tingkat pendidikan ibu yang kurang dari SLTA dan nilai 0 untuk tingkat pendidikan ibu SLTA ke atas.

4. Pekerjaan Orang Tua. Terdiri atas 4 kategori yaitu: Pegawai Negeri \& Pensiunan Pegawai Negeri; wiraswasta; Eksekutif, Profesional, Karyawan Swasta dan BUMN; serta Petani, Nelayan dan Lainnya.

5. Pendapatan Keluarga. Merupakan peubah biner dengan nilai 1 untuk pendapatan orang tua kurang dari Rp 1 juta (rendah) dan nilai 0 untuk pendapatan orang tua Rp 1 juta ke atas (tinggi).

6. Besar Keluarga. Terdiri atas tiga kategori yaitu: kurang dari atau sama dengan 4 orang, 5 - 6 orang, lebih dari 6 orang.

7. Status Proteinuria. Merupakan peubah biner dengan nilai 1 untuk mahasiswa yang mengalami proteinuria dan bernilai 0 untuk mahasiswa yang tidak memiliki proteinuria.

8. Riwayat Penyakit Alergi. Merupakan peubah biner dengan nilai 1 untuk mahasiswa yang pernah memiliki riwayat penyakit alergi dan 0 untuk mahasiswa yang tidak pernah memiliki riwayat penyakit alergi.

9. Asal Daerah. Peubah ini dibedakan menjadi dua kategori dengan asal daerah rural (kabupaten dan sekitarnya) bernilai 1 dan asal daerah urban (kotamadya) bernilai 0 .

10. Status Gizi. Merupakan hasil pengukuran secara antropometrik yang dibagi menjadi tiga kategori berdasarkan IMT/Umur yaitu kurus, normal dan gemuk. IMT (Indeks Massa Tubuh) dihitung berdasarkan berat badan dan tinggi badan mahasiswa yang bersangkutan yaitu:

$$
I M T=\frac{B B}{[T B(m)]^{2}}
$$

\section{Tahapan Analisis}

Tahapan analisis data dalam penelitian ini adalah :

1. Melakukan analisis data secara eksploratif untuk memperoleh gambaran secara rinci mengenai karakteristik umum mahasiswa USMI 2002/2003. 
2. Melakukan analisis regresi logistik yaitu:

a. Melakukan pendugaan parameter model persamaan fungsi logit.

b. Melakukan pengujian parameter dengan statistik uji-G dan statistik ujiWald.

c. Melakukan interpretasi hasil regresi logistik.

Software yang digunakan dalam penelitian ini adalah Microsoft Excel dan SPSS 10.0 for Windows.

\section{Regresi Logistik}

Model regresi yang dipilih adalah regresi logistik karena dapat menggambarkan hubungan antara satu atau beberapa peubah penjelas dengan sebuah peubah respon yang berskala biner (dikotom). Peubah respon $Y$ mengikuti sebaran Benoulli (McCullagh \& Nelder, 1983) dengan fungsi sebaran peluang :

$$
F(Y=y)=\pi^{y}(1-\pi)^{1-y}
$$

Dengan : $y=0$ atau $y=1$

$$
\pi \text { : peluang terjadinya } Y=1
$$

Secara umum model respons biner pada regresi untuk $\mathrm{p}$ peubah bebas adalah :

$$
y=E(Y \mid x)+\varepsilon
$$

dimana $\varepsilon$ adalah komponen acak

Jika fungsí penghubung yang digunakan adalah fungsi logik, maka sebaran peluang yang digunakan adalah sebaran logistik, sehingga nilai harapan bersyarat $Y$ jika diketahui $X$ adalah :

$$
E(Y \mid X)=\Pi(X)=\frac{e^{g(x)}}{1+e^{g(x)}}
$$

(Hosmer \& Lameshow, 2000). Transformasi logit sebagai fungsi $\pi(x)$ didefinisikan sebagai:

$$
g(x)=\ln \left[\frac{\pi(\mathrm{x})}{1-\pi(x)}\right]=\beta_{0}+\beta_{1} x_{1}+\beta_{2} x_{2}+\ldots+\beta_{p} x_{p}
$$

Model regresi biner menetapkan $E(Y \mid$ $X)=\pi(X)$ dan $\operatorname{var}(Y \mid X)=\pi(X)[1-\pi(X)]$, sehingga model responnya menjadi $y=\pi(X)+$ $\varepsilon$. Galat $\varepsilon$ hanya menghasilkan dua kemungkinan nilai. Jika $y=1$ maka $\varepsilon=1-\pi(X)$ dengan peluang $\pi(X)$, dan jika $y=0$ maka $\varepsilon=-\pi(X)$ dengan peluang $1-\pi(X)$. Dengan demikian $\varepsilon$ memiliki sebaran dengan rataan nol dan ragam sebesar $\pi(X)[1-\pi(X)]$. Oleh karena itu, sebaran bersyarat dari peubah respon mengikuti sebaran binomial dengan peluang yang diberikan oleh rataan bersyarat, $\pi(\mathrm{X})$ (Hosmer \& Lameshow, 2000).

\section{Peubah Boneka}

Apabila satu atau beberapa peubah penjelas merupakan peubah kategorik atau diskret (berskala nominal), maka tidak sesuai jika langsung memasukkan peubah-peubah tersesebut dalam model seolah-olah mereka berskala interval. Jika sebuah peubah berskala nominal (peubah kategorik atau diskret) memiliki $k$ kategori, maka diperlukan peubah boneka (dummy variable) sebanyak ( $k-1)$ untuk digunakan di dalam model (Hosmer dan Lameshow, 2000)

Dalam penelitian ini digunakan sepuluh buah peubah penjelas yang seluruh peubahnya merupakan peubah kategorik atau diskret. Oleh karena itu, transformasi logit untuk sepuluh buah peubah kategorik (diskret) yang digunakan tersebut adalah :

$$
g(x)=\beta_{0}+\sum_{j=1}^{10} \sum_{l=1}^{k_{j}-1} \beta_{j l} D_{j l}
$$

Dengan :

$D_{j l}=$ Peubah boneka pada peubah penjelas ke- $j$ dan kategori ke-l

$B_{j l}=$ Koefesien peubah boneka pada peubah penjelas ke- $j$ dan kategori ke-l

$k_{j}=$ Banyaknya kategori pada peubah penjelas ke-j

\section{Pendugaan Parameter Model}

Pada regresi linear umumnya digunakan metode kuadrat terkecil untuk menduga parameter $B$. Di bawah asumsi yang biasa digunakan untuk regresi linear (seperti misalnya asumsi kenormalan maupun kehomogenan ragam), metode kuadrat terkecil akan menghasilkan penduga parameter dengan sifat-sifat statistik yang diinginkan (tidak berbias dan memiliki ragam minimum). Namun apabila metode kuadrat terkecil ini diterapkan untuk model dengan peubah respon dikotom maka penduga parameter yang dihasilkan tidak lagi memiliki sifat-sifat statistik yang diinginkan tersebut (penduga parameternya tidak lagi tak berbias dan tidak lagi memiliki ragam minimum).

Oleh karena itu, pendekatan yang digunakan untuk mengatasi hal tersebut adalah melakukan pendugaan parameter $B$ dengan memaksimumkan fungsi logaritma kemungkinannya (log-likelihood), yaitu :

$$
L(\beta)=\sum_{i=1}^{n}\left\{y_{i} \ln \left[\pi\left(x_{i}\right)\right]+\left(1-y_{i}\right) \ln \left[1-\pi\left(x_{i}\right)\right]\right\}
$$

sehingga didapatkan $\hat{\beta}$ yang merupakan penduga kemungkinan maksimum. Penduga kemungkinan maksimum bagi parameter-parame- 
ter model diperoleh dengan metode kuadrat terkecil terboboti secara iteratif (Hosmer \& Lameshow, 2000).

\section{Uji Taraf Nyata Parameter}

Pengujian terhadap parameter model dilakukan untuk memeriksa peranan peubahpeubah penjelasnya dalam model.

Statistik uji-G adalah uji rasio kemungkinan maksimum (likelihood ratio test) yang digunakan untuk menguji peranan peubah penjelas di dalam model secara bersama-sama (Hosmer \& Lameshow, 2000)

Hipotesis yang diuji adalah :

$\mathrm{H}_{0}: B_{1}=B_{2}=\ldots=B_{p}=0$

$\mathrm{H}_{1}$ : paling sedikit ada satu $B_{i} \neq 0$

Statistik uji-G didefinisikan sebagai :

Dengan:

$$
G=-2 \ln \left[\frac{L_{o}}{L_{p}}\right]
$$

$\mathrm{L}_{\mathrm{o}}=$ likelihood tanpa peubah penjelas

$L_{p}=$ likelihood dengan $\mathrm{p}$ peubah penjelas

Statistik uji-G ini mengikuti sebaran $x^{2}$ dengan derajat bebas p. Hipotesis nol ditolak jika $\mathrm{G}>x_{p(a)}^{2}$.

Statistik uji-Wald digunakan untuk menguji parameter $B_{j}$ satu persatu secara parsial (Hosmer \& Lameshow, 2000).

Hipotesis yang diuji adalah :

$\mathrm{H}_{0}: B_{j}=0$

$\mathrm{H}_{1}: B_{i} \neq 0$

Statistik uji-Wald didefinisikan sebagai :

$$
W=\frac{\hat{\beta}}{\hat{S E}\left(\hat{\beta}_{j}\right)}
$$

Statistik uji-Wald ini mengikuti sebaran normal baku. Hipotesis nol ditolak jika $|W|>Z_{\alpha / 2}$.

\section{Interpretasi Koefesien}

Interpretasi koefesien untuk model regresi logistik dapat dilakukan dengan melihat odds ratio-nya. Odds Ratio (OR) ini didefinisikan sebagai :

$$
\Psi=\exp \left(\beta_{j}\right)=\exp [g(1)-g(0)]
$$

Dengan koefesien model logit $\left(B_{j}\right)$ mencerminkan perubahan nilai fungís logit $g(x)$ untuk perubahan satu unit peubah bebas $x$ (Hosmer \& Lameshow, 2000).

Dalam penelitian yang digunakan ini, untuk setiap peubah penjelas kategorik (peubah berskala nominal), populasi individu dapat dibagi menjadi dua buah sub populasi yaitu sub populasi dengan nilai $x=1$ dan sub populasi dengan nilai $x=0$. Odds ratio (OR) dapat diinterpretasikan sebagai risiko untuk memiliki $Y=$ 1 (mengalami anemia) pada sub populasi dengan nilai $X=1$ adalah sebesar $\psi$ kali dibanding populasi dengan nilai $X=0$ (Hosmer \& Lameshow, 2000)

\section{HASIL DAN PEMBAHASAN}

\section{Eksplorasi Data}

Berdasarkan data mahasiswa USMI IPB tahun 2002/2003 yang ada, dari 1907 data mahasiswa yang lengkap, terdapat sebanyak 208 (10.91\%) mahasiswa yang menderita anemia dan 1699 (89.09\%) mahasiswa yang tidak menderita anemia gizi. Pada kelompok mahasiswa perempuan, persentase yang menderita anemia tersebut lebih tinggi yaitu ada sebanyak 134 (12.2\%) mahasiswa, sedangkan pada kelompok mahasiswa laki-laki hanya sebanyak 74 (9.1\%) mahasiswa (Tabel 1).

Sebagian besar mahasiswa berusia 18 20 tahun dengan pendidikan ibu $\geq$ SLTA dan sekitar 50\% ayahnya adalah pegawai negeri serta pensiunan. Selain itu, sebaran karakteristik mahasiswa (profil mahasiswa) USMI IPB tahun 2002/2003 disajikan pada Tabel 2.

Berdasarkan hasil tabulasi silang data awal antara status anemia dengan faktorfaktor risikonya (Tabel 1), secara umum terlihat bahwa mahasiswa memiliki kecenderungan yang lebih besar untuk menderita anemia gizi apabila berjenis kelamin perempuan dan berusia 18 tahun ke atas. Menurut tingkat pendidikan ibu, kebanyakan mahasiswa yang menderita anemia gizi ini memiliki ibu yang tingkat pendidikannya SLTA ke atas. Dari jenis pekerjaan orang tua, rata-rata mahasiswa yang cenderung menderita anemia gizi memiliki orang tua yang bekerja sebagai pegawai negeri dan pensiunan pegawai negeri, dengan pendapatan orang tua berkisar Rp 1000000 atau lebih, serta besar keluarga sebanyak 5 - 6 orang. Selain itu berdasarkan hasil tabulasi silang data awal ini juga terlihat bahwa mahasiswa yang cenderung menderita anemia tidak mengalami proteinuria ataupun memiliki riwayat alergi. Berdasarkan asal daerah, mahasiswa yang menderita anemia lebih banyak berasal dari daerah urban (kotamadya dan sekitarnya), dan kebanyakan pula mahasiswa yang anemia tersebut memiliki status gizi normal. 
Tabel 1. Tabulasi Silang Status Anemia menurut Faktor Risikonya.

\begin{tabular}{|c|c|c|c|c|c|c|c|}
\hline & \multirow{3}{*}{ Faktor Risiko } & \multicolumn{4}{|c|}{ Status Anemia } & \multirow{3}{*}{$\begin{array}{c}\text { Nilai Khi- } \\
\text { kuadrat }\left(X^{2}\right)\end{array}$} & \multirow{3}{*}{ P-value } \\
\hline & & \multicolumn{2}{|c|}{ Anemia } & \multicolumn{2}{|c|}{ Tidak Anemia } & & \\
\hline & & Jumlah & Persen (\%) & Jumlah & Persen (\%) & & \\
\hline \multirow{2}{*}{ Jenis kelamin } & - Laki-laki & 74 & 9.1 & 738 & 90.9 & \multirow{2}{*}{4.683} & \multirow{2}{*}{$0.030^{*}$} \\
\hline & - Perempuan & 134 & 12.2 & 961 & 87.8 & & \\
\hline \multirow{2}{*}{ Umur } & $\bullet<18$ tahun & 99 & 13.1 & 656 & 86.9 & \multirow{2}{*}{6.256} & \multirow{2}{*}{$0.012^{*}$} \\
\hline & $\cdot \geq 18$ tahun & 109 & 9.5 & 1043 & 90.5 & & \\
\hline \multirow{2}{*}{ Pendidikan Ibu } & - SLTA ke atas & 141 & 11.1 & 1127 & 88.9 & \multirow{2}{*}{0.176} & \multirow{2}{*}{0.675} \\
\hline & $\cdot<$ SLTA & 67 & 10.5 & 572 & 89.5 & & \\
\hline \multirow{4}{*}{$\begin{array}{l}\text { Pekerjaan Orang } \\
\text { tua }\end{array}$} & - P.Negeri \& Pens. P Negeri & 104 & 11.5 & 801 & 88.5 & \multirow{4}{*}{2.756} & \multirow{4}{*}{0.431} \\
\hline & - Wiraswasta & 44 & 10.0 & 394 & 90.0 & & \\
\hline & $\begin{array}{l}- \text { Eksekutif, Professional, } \\
\text { K.Swasta \& BUMN }\end{array}$ & 43 & 12.1 & 313 & 87.9 & & \\
\hline & - Petai, Nelayan, Lainnya & 17 & 8.2 & 191 & 91.8 & & \\
\hline \multirow{2}{*}{\begin{tabular}{|l} 
Pendapatan \\
Orang tua
\end{tabular}} & $\cdot \geq 1000000$ & 168 & 10.4 & 1451 & 89.6 & \multirow{2}{*}{3.104} & \multirow{2}{*}{$0.078^{*}$} \\
\hline & $\cdot<1000000$ & 40 & 13.9 & 248 & 86.1 & & \\
\hline \multirow{3}{*}{ Besar Keluarga } & $\bullet<4$ orang & 52 & 10.8 & 430 & 89.2 & \multirow{3}{*}{0.121} & \multirow{3}{*}{0.941} \\
\hline & - 5 - 6 orang & 111 & 10.8 & 919 & 89.2 & & \\
\hline & $\cdot>6$ orang & 45 & 11.4 & 350 & 88.6 & & \\
\hline \multirow{2}{*}{\begin{tabular}{|l} 
Status \\
Proteinuria
\end{tabular}} & - Tidak & 152 & 10.1 & 1346 & 89.9 & \multirow{2}{*}{4.155} & \multirow{2}{*}{$0.042^{*}$} \\
\hline & $\cdot$ - Ya & 56 & 13.7 & 353 & 86.3 & & \\
\hline \multirow{2}{*}{ Riwayat Alergi } & - Tidak & 189 & 10.7 & 1572 & 89.3 & \multirow{2}{*}{0.722} & \multirow{2}{*}{0.395} \\
\hline & $\cdot \mathrm{Ya}$ & 19 & 13.0 & 127 & 87.0 & & \\
\hline \multirow{2}{*}{ Asal Daerah } & - Kotamadya/ urban & 120 & 10.4 & 1031 & 89.6 & \multirow{2}{*}{0.693} & 0405 \\
\hline & - Kabupaten/ rural & 88 & 11.6 & 668 & 88.4 & & 0.405 \\
\hline & $\cdot$ Kurus & 14 & 7.8 & 165 & 92.2 & & \\
\hline Status Gizi & - Normal & 179 & 11.1 & 1433 & 88.9 & 2.308 & 0.315 \\
\hline & - Gemuk & 15 & 12.9 & 101 & 87.1 & & \\
\hline
\end{tabular}

Tabel 2. Sebaran Karakteristik Mahasiswa USMI IPB 2002/2003

\begin{tabular}{|c|c|c|}
\hline Faktor Risiko & Jumlah & Persentase (\%) \\
\hline $\begin{array}{ll}\text { Jenis } & \text { Kelamin } \\
\bullet & \text { Laki-laki } \\
- & \text { Perempuan }\end{array}$ & $\begin{array}{l}812 \\
109\end{array}$ & $\begin{array}{l}42.6 \\
57.4\end{array}$ \\
\hline $\begin{array}{l}\text { Umur } \\
\bullet \quad<18 \text { tahun } \\
\bullet \quad \geq 18 \text { tahun }\end{array}$ & $\begin{array}{c}755 \\
1152\end{array}$ & $\begin{array}{l}39.6 \\
60.4\end{array}$ \\
\hline $\begin{array}{l}\text { Pendidikan Ibu } \\
\text { - } \quad \text { SLTA ke atas } \\
\text { - } \quad \text { SLTA }\end{array}$ & $\begin{array}{c}1268 \\
639\end{array}$ & $\begin{array}{l}66.5 \\
33.5\end{array}$ \\
\hline $\begin{array}{ll}\text { Pekerjaan Ayah } \\
\text { - } & \text { P. Ngr \& Pens. } \\
\text { - } & \text { Wiraswasta } \\
\text { - } & \text { Eksktf, Prof \& BUMN } \\
\text { - } & \text { Ptni, Nlyn, lainnya }\end{array}$ & $\begin{array}{l}905 \\
438 \\
356 \\
208\end{array}$ & $\begin{array}{l}47.5 \\
23.0 \\
18.7 \\
10.9\end{array}$ \\
\hline $\begin{array}{l}\text { Pendapatan Keluarga } \\
-\quad \geq 1000000 \\
-\quad<1000000\end{array}$ & $\begin{array}{c}1619 \\
288\end{array}$ & $\begin{array}{l}84.9 \\
15.1\end{array}$ \\
\hline 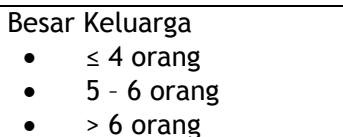 & $\begin{array}{c}482 \\
1030 \\
395\end{array}$ & $\begin{array}{l}25.3 \\
54.0 \\
20.7\end{array}$ \\
\hline $\begin{array}{l}\text { Status Proteinuria } \\
\text { - Tidak } \\
\text { - } \quad \text { Ya }\end{array}$ & $\begin{array}{c}1498 \\
409\end{array}$ & $\begin{array}{l}78.6 \\
21.4\end{array}$ \\
\hline $\begin{array}{l}\text { Riwayat Alergi } \\
\text { - Tidak } \\
\text { - } \quad \text { Ya }\end{array}$ & $\begin{array}{c}1761 \\
146\end{array}$ & $\begin{array}{c}92.3 \\
7.7\end{array}$ \\
\hline $\begin{array}{l}\text { Asal Daerah } \\
\text { - Kotamadya / urban } \\
\text { - } \quad \text { Kabupaten / rural }\end{array}$ & $\begin{array}{c}1151 \\
756\end{array}$ & $\begin{array}{l}60.4 \\
39.6\end{array}$ \\
\hline $\begin{array}{ll}\text { Status Gizi } \\
\text { - } & \text { Kurus } \\
\text { - } & \text { Normal } \\
\text { - } & \text { Gemuk }\end{array}$ & $\begin{array}{c}179 \\
1612 \\
116\end{array}$ & $\begin{array}{c}9.4 \\
84.5 \\
6.1\end{array}$ \\
\hline
\end{tabular}




\section{Faktor Risiko yang Signifikan}

Pendugaan model logit yang dibentuk dengan menggunakan seluruh peubah penjelas (termasuk peubah dummy) menghasilkan nilai statistik nilai uji-G sebesar 26.28 (Tabel 3). Model tersebut memiliki nilai $\mathrm{p}=0.024$ yang berarti bahwa paling sedikit ada satu $B_{j}$ yang tidak sama dengan nol di antara seluruh peubah penjelas tersebut pada taraf nyata $10 \%$.

Berdasarkan uji Wald dari model logit yang dihasilkan tersebut, terlihat bahwa faktor risiko yang secara signifikan berpengaruh nyata pada taraf $\alpha=10 \%$ adalah faktor jenis kelamin, umur, pendapatan orang tua, dan status proteinuria dengan nilai-p dari masing-masing faktor risiko tersebut lebih kecil dari a. Sedangkan faktor risiko yang tidak signifkan taraf $a=10 \%$ adalah faktor pendidikan ibu, pekerjaan orang tua, besar keluarga, riwayat penyakit alergi, asal daerah, dan status gizi.

Dari model logit yang diperoleh, faktor risiko yang secara signifikan mempengaruhi kecenderungan status anemia gizi mahasiswa baru yaitu faktor jenis kelamin, umur, pendapatan keluarga dan status proteinuria. Nilai OR dari model logit untuk masing-masing faktor risiko disajikan pada Tabel 4.

Faktor risiko jenis kelamin, pendapatan keluarga, dan status proteinuria memiliki koefesien yang positif dan nilai OR yang lebih dari 1. Faktor jenis kelamin memiliki OR sebesar 1.36 (Tabel 4). Hal ini menunjukkan bahwa mahasiswa perempuan mempunyai kecenderungan untuk menderita anemia gizi 1.36 kali lebih besar dibandingkan dengan laki-laki.

Hal ini antara lain disebabkan karena perempuan mengalami menstruasi setiap bulan sehingga membutuhkan zat besi lebih banyak daripada laki-laki. Selain itu, hal ini juga dapat terjadi karena perempuan umumnya lebih jarang mengonsumsi makanan hewani dan sering melakukan diit pengurangan makan karena ingin langsing, sehingga hal ini mengakibatkan pasokan zat besi yang dibutuhkan menjadi berkurang (Depkes, 1998).

Tabel 4. Nilai Odds Ratio (OR) untuk Faktor Risiko Status Anemia Gizi

\begin{tabular}{|c|c|}
\hline Faktor Risiko & Odds ratio (OR) \\
\hline $\begin{array}{l}\text { Jenis Kelamin } \\
\quad \text { Laki-laki }=0 \\
\text { Perempuan } \\
\text { Umur } \\
\quad<18 \text { tahun }=0 \\
\geq 18 \text { tahun } \\
\text { Pendapatan Keluarga } \\
\quad \geq 1 \text { juta }=0 \\
\quad<1 \text { juta } \\
\text { Proteinuria } \\
\text { Tidak mengalami = } 0 \\
\text { Mengalami proteinuria }\end{array}$ & 0.71 \\
\hline
\end{tabular}

Nilai koefesien yang positif dan OR yang lebih dari 1 pada faktor pendapatan keluarga menunjukkan bahwa dengan semakin menurunnya pendapatan keluarga maka kecenderungan mahasiswa untuk menderita anemia gizi makin meningkat sebesar nilai OR-nya. Dengan tingkat OR sebesar 1.70 (Tabel 4), kelompok mahasiswa dengan tingkat pendapatan keluarga relatif rendah (kurang dari Rp 1000000 ) memiliki kecenderungan untuk menderita anemia gizi sebesar 1.70 kali lebih besar daripada kelompok mahasiswa dengan pendapatan keluarga relatif tinggi (Rp 1 juta

Tabel 3. Dugaan Parameter Model Logit untuk Status Anemia

\begin{tabular}{|c|c|c|c|c|c|c|}
\hline \multicolumn{2}{|r|}{ Peubah } & $B_{j}$ & SE & Wald & P-value & $\operatorname{Exp}(B)=0 R$ \\
\hline \multicolumn{2}{|l|}{ Konstanta } & -2.57 & 0.35 & 54.54 & 0.00 & 0.08 \\
\hline Jenis kelamin & $($ laki-laki $=0$, perempuan $=1)$ & 0.31 & 0.16 & 3.78 & $0.05^{*}$ & 1.36 \\
\hline Umur & $(<18$ th $=0, \geq 18$ th $=1)$ & -0.34 & 0.15 & 5.19 & $0.02^{*}$ & 0.71 \\
\hline Pendidikan ibu & $(\geq \mathrm{SLTA}=0,<\mathrm{SLTA}=1)$ & 0.05 & 0.18 & 0.08 & 0.78 & 1.05 \\
\hline \multirow[t]{3}{*}{ Pekerjaan orang tua } & : Wiraswasta & -0.19 & 0.19 & 0.95 & 0.33 & 0.83 \\
\hline & \multirow{2}{*}{$\begin{array}{l}\text { : Eksekutif, Profesional, Swasta, BUMN } \\
\text { : Petani, Nelayan, lainnya }\end{array}$} & 0.07 & 0.19 & 0.12 & 0.73 & 1.07 \\
\hline & & -0.53 & 0.30 & 3.06 & 0.08 & 0.59 \\
\hline \multicolumn{2}{|l|}{ Pendapatan Keluarga } & 0.53 & 0.21 & 6.58 & $0.01^{*}$ & 1.70 \\
\hline \multirow[t]{2}{*}{ Besar Keluarga } & $: 5-6$ orang & 0.04 & 0.18 & 0.05 & 0.82 & 1.04 \\
\hline & $:>6$ orang & 0.11 & 0.22 & 0.24 & 0.62 & 1.11 \\
\hline \multicolumn{2}{|r|}{$(\mathrm{tdk}$ proteinuria $=0$, proteinuria $=1)$} & 0.39 & 0.17 & 5.52 & $0.02^{*}$ & 1.49 \\
\hline $\begin{array}{l}(\text { tdk alergi }=0, \text { alergi }=1) \\
(\text { kota }=0, \text { kabupaten }=1)\end{array}$ & $\begin{array}{l}(\mathrm{tdk} \text { proteinuria }=0, \text { proteinuria }=1) \\
(\mathrm{tdk} \text { alergi }=0, \text { alergi }=1)\end{array}$ & 0.19 & 0.26 & 0.51 & 0.48 & 1.20 \\
\hline \multirow{3}{*}{$\begin{array}{l}\text { Asal Daerah } \\
\text { Status Gizi }\end{array}$} & $($ kota $=0$, kabupaten $=1)$ & 0.10 & 0.15 & 0.45 & 0.50 & 1.11 \\
\hline & \multirow{2}{*}{$\begin{array}{l}\text { : Normal } \\
: \text { Gemuk }\end{array}$} & 0.27 & 0.29 & 0.87 & 0.35 & 1.32 \\
\hline & & 0.41 & 0.40 & 1.09 & 0.30 & 1.52 \\
\hline \multicolumn{7}{|c|}{$\begin{array}{c}-2 \text { Log Likelihood }=1287.91 \\
\text { Statistik G }=26.28 \\
\text { P-value }=0.024\end{array}$} \\
\hline
\end{tabular}


atau lebih). Berdasarkan hasil tersebut, jelas terlihat bahwa pendapatan akan mempengaruhi daya beli terhadap pangan yang akan dikonsumsi. Dengan semakin meningkatnya pendapatan, maka akan terjadi perubahanperubahan dalam susunan makanan.

Pada umumnya kelompok dengan pendapatan yang rendah cenderung akan lebih banyak mengonsumsi bahan makanan sumber karbohidrat yang harganya relatif murah, sedangkan peningkatan pendapatan akan menyebabkan peningkatan pola konsumsi pangan yang semakin beragam dan semakin bernilai gizi tinggi (Hardinsyah \& Suhardjo, 1997).

Faktor status proteinuria juga menunjukkan peranan yang signifikan dalam mempengaruhi kecenderungan seseorang untuk menderita anemia gizi. Mahasiswa yang mengalami proteinuria cenderung untuk menderita anemia gizi 1.49 kali lebih besar dibandingkan mahasiswa yang tidak mengalami proteinuria.

Faktor umur memiliki pengaruh yang cukup signifikan terhadap status anemia mahasiswa dengan nilai koefesien yang negatif dan OR yang kurang dari 1 (Tabel 4). Nilai OR untuk faktor umur adalah sebesar 0.71 (Tabel 4), dimana hal ini menunjukkan bahwa mahasiswa yang berumur 18 tahun ke atas memiliki kecenderungan untuk menderita anemia gizi sebesar 0.71 kali lebih kecil daripada kecenderungan yang sama pada mahasiswa yang berumur kurang dari 18 tahun.

\section{Faktor Risiko yang Tidak Signifikan}

Sebagian faktor risiko yang semula diduga mempengaruhi kecenderungan status anemia ternyata dari hasil analisis regresi logistik belum ada cukup bukti untuk menunjukkan bahwa faktor-faktor tersebut secara signifikan mempengaruhi status anemia mahasiswa (Tabel 3). Faktor-faktor tersebut adalah faktor pendidikan ibu, pekerjaan orang tua, besar keluarga, riwayat penyakit alergi, asal daerah dan status gizi. Apabila dilihat dari hasil khikuadratnya, keenam faktor risiko tersebut juga memang menunjukkan hasil bahwa belum ada cukup bukti yang signifikan untuk menunjukkan bahwa faktor-faktor tersebut mempengaruhi status anemia gizi mahasiswa karena faktor-faktor tersebut memiliki nilai-p yang lebih besar dari $a=10 \%$ (Tabel 1).

Menurut dugaan, faktor pendidikan ibu merupakan salah satu faktor yang mempengaruhi status anemia. Umumnya faktor tingkat pendidikan erat kaitannya dengan makanan yang dikonsumsi oleh anggota keluarga dan berkaitan dengan pengetahuan yang lebih tinggi, terutama tentang gizi dan kesehatan (Nurhayati, 1997). Namun ternyata dalam model logit yang diperoleh, faktor pendidikan ibu tidak menunjukkan pengaruh yang signifikan terhadap status anemia gizi. Hal ini mungkin dikarenakan kecilnya persentase mahasiswa dengan ibu yang berpendidikan rendah. Umumnya tingkat pendidikan ibu dari mahasiswa IPB ini kebanyakan SLTA ke atas sehingga variasi pada data penelitian ini relatif kecil.

Pekerjaan orang tua juga tidak mempengaruhi status anemia. Hal ini diantaranya dimungkinkan karena tidak adanya suatu patokan yang pasti bahwa suatu pekerjaan lebih baik daripada pekerjaan yang lain, dari sisi pendapatan. Pekerjaan yang mungkin oleh sebagian orang dianggap lebih baik belum tentu menghasilkan pendapatan yang lebih banyak pula. Selain itu, bisa jadi orang tua juga memiliki pekerjaan sambilan yang lain, sehingga hal itu juga dapat menambah pendapatan keluarga yang akhirnya berakibat terhadap pola pemenuhan konsumsi keluarga itu sendiri. Oleh karena itu kecenderungan status anemia gizi yang diduga disebabkan oleh status sosial pekerjaan yang dianggap kurang baik, pada penelitian ini cenderung tidak signifikan.

Faktor lainnya yang juga tidak berpengaruh secara signifikan pada taraf $a=10 \%$ adalah faktor besar keluarga. Menurut Sanjur (1982) dalam Hayatinur (2001), umumnya besar keluarga akan berpengaruh pada pembelanjaan dan konsumsi pangan keluarga. Pemenuhan kebutuhan makanan, terutama jenis makanan pangan hewani yang relatif lebih mahal, akan lebih mudah jika yang harus diberi makan jumlahnya sedikit. Hal ini terutama sangat terasa pada keluarga yang sangat miskin dan memiliki pendapatan yang sangat kecil, sedangkan anggota keluarganya cukup banyak. Namun dalam penelitian ini peubah besar keluarga tidak memiliki pengaruh yang signifikan dalam menunjukkan kecenderungan status anemia mungkin di antaranya disebabkan oleh besar keluarga berbanding lurus dengan pendapatan keluarga. Apabila suatu keluarga memiliki besar keluarga yang cukup banyak namun juga sekaligus memiliki tingkat pendapatan yang cukup besar, maka hal tersebut tidak akan menjadi masalah karena keluarga itu masih dapat memenuhi kebutuhan konsumsi pangan dan gizi yang dibutuhkan, terutama pangan hewani yang sangat dibutuhkan untuk mencegah anemia gizi.

Faktor riwayat penyakit alergi tidak memiliki pengaruh yang signifikan terhadap status anemia gizi mungkin dikarenakan kurang jelas- 
nya jenis alergi yang diungkapkan mahasiswa, apakah alergi karena suatu jenis makanan hewani, ataukah alergi karena hal lain, misalnya alergi cuaca dingin dan sebagainya yang sama sekali tidak ada hubungannya dengan hal-hal yang mempengaruhi kejadian anemia gizi. Sehingga apabila untuk selanjutnya ingin diteliti apakah riwayat penyakit alergi sebenarnya mempengaruhi status anemia gizi atau tidak, ada baiknya lebih dispesifikasikan lagi jenis alergi yang terkait pangan hewani.

Asal daerah mahasiswa diduga memiliki pengaruh terhadap status anemia gizi karena seseorang yang berasal dari daerah pedesaan cenderung lebih banyak mengonsumsi jenis bahan pangan nabati daripada pangan hewani yang merupakan sumber zat besi yang baik. Namun dalam penelitian ini asal daerah mahasiswa ternyata belum menunjukkan bukti yang signifikan mempengaruhi status anemia. Hal ini mungkin karena perbedaan asal daerah yang digunakan masih kurang mencerminkan perbedaan yang jelas antara pedesaan dan perkotaan yang diinginkan karena hanya dibedakan berdasarkan alamat yang ada.

Faktor yang juga tidak berpengaruh terhadap status anemia gizi mahasiswa adalah status gizi yang diukur berdasarkan indeks massa tubuh menurut umur sebagai wujud intake gizi makro, sedangkan anemia gizi terutama sebagai wujud masalah gizi mikro (Depkes, 1998). Hal ini kemungkinan disebabkan oleh persentase mahasiswa dengan status gizi kurang yang relatif kecil sehingga variasi pada data penelitian ini juga relatif kecil.

\section{KESIMPULAN DAN SARAN}

\section{Kesimpulan}

1. Faktor risiko yang signifikan mempengaruhi status anemia pada mahasiswa baru IPB tahun 2002/2003 adalah faktor jenis kelamin, umur, pendapatan orang tua, dan status proteinuria. Mahasiswa cenderung untuk menderita anemia gizi apabila ia seorang perempuan, berumur kurang dari 18 tahun, pendapatan orang tua relatif rendah, dan mengalami proteinuria.

2. Dalam konteks kajian anemia gizi mahasiswa perempuan berisiko $40 \%$ lebih tinggi dibanding mahasiswa laki-laki. Mahasiswa dari keluarga tidak mampu berisiko $70 \%$ lebih tinggi dibanding mahasiswa dari keluarga mampu dan mahasiswa yang menderita proteinuria berisiko $50 \%$ lebih tinggi dibanding yang tidak.
3. Penelitian ini juga menunjukkan bahwa belum ada cukup bukti faktor pendidikan ibu, pekerjaan orang tua, besar keluarga, riwayat penyakit alergi, asal daerah, dan status gizi, mempengaruhi status anemia mahasiswa secara siginifikan.

\section{Saran}

Ada baiknya Poliklinik IPB melakukan pemantauan status kesehatan dan anemia gizi mahasiswa secara terus menerus (setiap tahun) dan melakukan upaya penanggulangan. Perlu kajian lebih mendalam tentang faktorfaktor lain yang diduga mempengaruhi tapi tidak ditemukan bukti yang signifikan pada penelitian ini.

\section{DAFTAR PUSTAKA}

Depkes. 1998. Pedoman Penanggulangan Anemia Gizi Untuk Remaja Putri dan Wanita Usia Subur. Depkes. Jakarta.

Hardinsyah \& Suhardjo. 1997. Ekonomi Gizi. Jurusan Gizi Masyarakat dan Sumberdaya Keluarga, Fakultas Pertanian, IPB, Bogor.

Hayatinur E. 2001. Prevalensi Anemia dan Perilaku Makan Remaja Putri di SMUN 2 Kuningan, Kabupaten Kuningan. Skripsi. Jurusan Gizi Masyarakat dan Sumberdaya Keluarga, Faperta, IPB. Bogor.

Hosmer DW dan Lameshow S. 2000. Applied Logistic Regression 2 $2^{\text {nd }}$ Edition. John Wiley \& Sons, New York.

Husaini MA dan Karyadi D. 1978. Buku Pedoman Anemia Gizi Penetapan Masalah Pencegahan dan Pengobatan. Puslitbang Gizi, Depkes. Bogor.

McCullagh P dan Nelder JA. 1983. Generallized Linear Model. Chapman, London.

Nurhayati SD. 1997. Keragaan konsumsi pangan, status Gizi dan status anemia pada remaja wanita di SMUN 4 Bogor. Skripsi Sarjana Jurusan Gizi Masyarakat dan Sumberdaya Keluarga, Faperta, IPB. Bogor.

Soekirman. 2000. Ilmu Gizi dan Aplikasinya untuk Keluarga dan Masyarakat. Direktorat Jenderal Pendidikan Tinggi, Pusat Antar Universitas Pangan dan Gizi, IPB. Bogor. 
Jurnal Gizi dan Pangan, Juli 2007 2(2): 36 - 43 